\title{
PELATIHAN OPERASIONAL PERBANKAN SYARIAH BAGI KSPPS BMT PENITI KAHURIPAN MULIYA
}

\author{
Sholikha Oktavi Khalifaturofi'ah ${ }^{1}$, Elfira Maya Adiba ${ }^{2}, Z^{2}$ ubaidah Nasution ${ }^{3}$ \\ ${ }^{1}$ Departemen Manajemen, ${ }^{2}$ Program Studi Ekonomi Syariah \\ ${ }^{3}$ Departemen Ekonomi Syariah \\ ${ }^{1,3}$ STIE Perbanas Surabaya, ${ }^{2}$ Universitas Trunojoyo Madura \\ Email: sholikha@ perbanas.ac.id
}

\begin{abstract}
One of the problems in Islamic microfinance institutions is the availability of human resources who understand and are qualified in Islamic banking operations. The development of professionalism of lecturers in the field of teaching regarding Islamic bank operation laboratories has been related to the problem of lack of understanding of human resources in BMT. The purpose of this activity is to provide training on Islamic banking operations. This training was attended by 5 employees of KSPPS BMT Peniti Kahuripan Muliya. The training participants came from three BMT branch offices, namely the Surabaya branch, the Boyolali branch, and the Bandung branch. The methods used are 1) providing theoretical and practical knowledge about Islamic banking operations 2) assistance in the roleplay of Islamic banking operations. The results of this activity are: First, all participants of this training activity are very enthusiastic and highly motivated to participate in the implementation of Islamic banking operational training activities. Second, the participants who attended the training as a whole were 60\% of all training participants.
\end{abstract}

Keywords: Training, Syariah banking operations, BMT

\begin{abstract}
Abstrak. Salah satu masalah dalam lembaga keuangan mikro syariah adalah ketersediaan SDM yang memahami dan mumpuni dalam operasional perbankan syariah. Pengembangan profesionalisme dosen pada bidang pengajaran tentang laboratorium operasi bank syariah selama ini terkait dengan persoalan kurangnya pemahaman SDM di BMT. Tujuan kegiatan ini adalah untuk memberikan pelatihan tentang operasional perbankan syariah. Pelatihan ini diikuti oleh para karyawan KSPPS BMT Peniti kahuripan Muliya sebanyak 5 orang. Peserta pelatihan berasal dari tiga kantor cabang BMT yaitu cabang Surabaya, cabang Boyolali, dan Cabang Bandung. Metode yang digunakan adalah 1) pemberian pengetahuan teoretis dan praktis tentang operasional perbankan syariah 2) pendampingan dalam roleplay operasional perbankan syariah. Hasil kegiatan ini adalah : Pertama, semua peserta kegiatan pelatihan ini sangat antusias, bersemangat, dan mempunyai motivasi yang tinggi mengikuti pelaksanaan kegiatan pelatihan operasional perbankan syariah. Kedua, peserta kegiatan yang mengikuti pelatihan secara keseluruhan adalah $60 \%$ dari semua peserta pelatihan.
\end{abstract}

Kata kunci : Pelatihan, Operasional perbankan syariah, BMT

\section{PENDAHULUAN}

KSPPS BMT Kahuripan Muliya adalah salah satu lembaga keuangan mikro syariah yang melayani simpan dan pinjam secara syariah. BMT tersebut baru beroperasi pada 10 Januari 2018. KSPPS BMT Kahuripan Muliya ini berada dalam naungan Kementerian Koperasi dan UKM (Masyithoh, 2014; Aryani dkk, 2018). Dalam proses operasionalnya BMT tidak terlalu bankable dibandingkan dengan BPRS, karena mengacu kepada peraturan BI (Sakti, 2013). BMT ini dapat beroperasi secara nasional dimana
KSPPS BMT ini selain terdapat di Surabaya juga memiliki cabang di Bandung dan Boyolali.

KSPPS BMT Kahuripan Muliya saat ini memiliki karyawan pada masing-masing cabang tidak lebih dari 5 orang. Aset yang dimiliki saat ini sudah mencapai 1,2 Milyar dengan total dana pihak ketiga (DPK) 734 juta. Total pembiayaan per 2018 sebesar 1,89 Milyar dengan status open 1 Milyar dan sisanya statusnya adalah lunas. Jumlah anggotanya saat ini adalah 274 orang. Berikut adalah gambar dari KSPPS BMT Peniti Kahuripan Muliya 


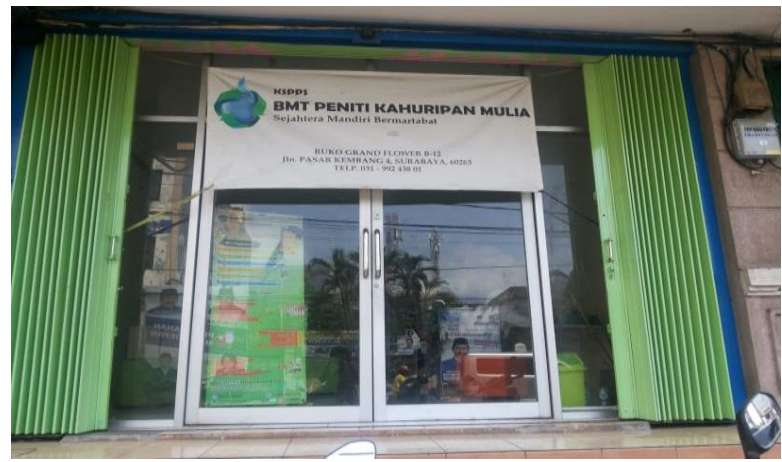

Gambar 1 Kantor BMT Cabang Surabaya (tampak depan)

Jumlah karyawan dalam BMT ini sekitar 12 orang yang meliputi karyawan dari Surabaya, Bandung, dan Boyolali. Karena tergolong masih baru, BMT ini membutuhkan beberapa pemahaman dan pelatihan bagi karyawan agar dapat meningkatkan kinerja SDM (Dehotman, 2016). Jika pemahaman karyawan meningkat maka diharapkan terdapat peningkatan pada kinerja karyawan di BMT. Hal ini berdasar pada penelitian Mu'awwanah (2015) yang menjelaskan bahwa pengetahuan tentang ekonomi islam berpengaruh terhadap kinerja karyawan pada BMT Sidogiri.
Sebagai lembaga keuangan mikro syariah yang baru, BMT ini masih perlu untuk melakukan edukasi dan pembinaan pada para karyawannya. Menurut BI, upaya pengembangan lembaga keuangan mikro syariah yang berbasis BMT ini perlu ditingkatkan karena masih terbatasnya jumlah lembaga keuangan mikro syariah non bank ini (Primadhyta, 2017). Akibatnya, peran lembaga keuangan mikro syariah ini terhadap perekonomian masih sangat kecil dibandingkan dengan lembaga keuangan perbankan konvensional dan Syariah (Qadariyah dan Permata, 2017)

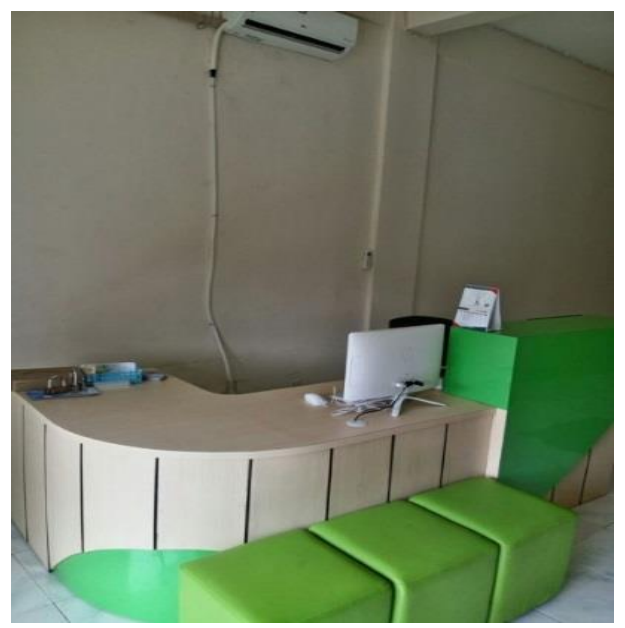

\section{Gambar 2 Ruang Front Office di BMT Peniti Kahuripan Muliya}

Permasalahan yang dihadapi oleh KSPPS BMT Peniti Kahuripan Muliya adalah keterbatasan SDM yang memahami tentang operasional perbankan syariah dan prinsip dasar ekonomi syariah. Karena tergolong baru, karyawan BMT KSPSS Peniti Kahuripan Muliya ini perlu mengetahui dan memahami tentang prinsip dasar operasional perbankan syariah sebelum akhirnya dapat memiliki keterampilan dalam menjalankan peran di BMT.

Permasalahan ini adalah permasalahan umum yang juga dialami oleh BMT-BMT yang lainnya. Menurut Ridha (2019), hal ini disebabkan oleh belum memadainya sumber daya manusia yang terdidik dan profesional, jiwa wirausaha (entrepreneurship) yang masih lemah, permodalan (dana) yang relatif kecil dan terbatas, 
adanya ambivalensi antara konsep syariah pengelolaan BMT dengan operasionalisasi di lapangan, tingkat kepercayaan yang masih rendah dari umat Islam dan secara akademik belum terumuskan dengan sempurna untuk mengembangkan lembaga keuangan syariah dengan cara sistematis dan proporsional. Kompleksitas persoalan tersebut menimbulkan dampak terhadap kepercayaan masyarakat tentang keberadaan BMT di antara lembaga keuangan konvensional.

Oleh karena itu, solusi dari permasalahan mitra tersebut adalah dibutuhkan pendampingan dan pelatihan bagi karyawan BMT dalam operasional perbankan Syariah (Khoirudin dan Akbar, 2016). Di samping itu, tujuan adanya pendampingan dan pelatihan ini adalah untuk mengenalkan operasional perbankan syariah bagi para karyawan KSPPS BMT Peniti Kahuripan Muliya beserta prinsip dasar dalam perbankan syariah. Pendampingan yang diberikan disarankan dari instruktur yang mengerti dan memahami operasional perbankan Syariah karena operasional BMT hampir sama dengan operasional perbankan Syariah (Harahap dan Ghozali, 2020).

Pendampingan dan pelatihan ini dilakukan dengan pendekatan IPTEKS. Pada waktu pendampingan dan pemberian materi pengetahuan terkait dengan hal-hal yang perlu dipelajari dalam operasional perbankan Syariah, tim pengabdian masyarakat menggunakan bantuan kahoot, google form, dan aplikasi bank Syariah perbanas, dan lab bank Syariah perbanas supaya mitra lebih memahami tentang operasional perbankan Syariah. Pendekatan inilah yang berbeda dengan pendekatan yang lainnya dimana pemberian materi hanya sekedarnya sedangkan pendampingan dan pelatihan yang dilakukan oleh tim mencakup roleplay juga.

Diharapkan dengan adanya pelatihan ini, maka dapat memberikan pengetahuan dan pemahaman kepada mitra terkait dengan operasional perbankan syariah. Selain itu, roleplay yang dilakukan berguna untuk meningkatkan skill karyawan BMT. Terakhir, yang terpenting adalah dengan adanya pelatihan ini, tercipta sinergi antara STIE Perbanas
Surabaya selaku perguruan tinggi bersama lembaga keuangan mikro syariah yaitu KSPPS BMT Kahuripan Muliya.

\section{METODE PELAKSANAAN}

Pelaksanaan program pengabdian kepada masyarakat ini dilakukan dengan beberapa tahapan. Tahap pertama adalah tahap penyelenggaraan pelatihan operasional perbankan syariah. Pelatihan ini diperuntukkan bagi karyawan KSPPS BMT Peniti Kahuripan Muliya. Pelatihan ini melibatkan karyawan dari tiga cabang yaitu cabang Bandung, Cabang Boyolali, dan Cabang Surabaya. Dalam tahap ini disampaikan materi yang terkait dengan prinsip operasional perbankan syariah.

Tahap kedua adalah diskusi yang mencakup tanya jawab atas materi yang disampaikan. Diskusi juga disampaikan dalam bentuk game pada aplikasi kahoot. Kahoot yaitu tanya jawab online yang melibatkan peserta pelatihan untuk menjawab pertanyaan yang diajukan melalui www.kahoot.it. Manfaat dari pelaksanaan game kahoot ini adalah terukurnya sampai mana materi dapat diserap oleh peserta pelatihan. Game kahoot ini berisi materi yang telah disampaikan oleh pemateri sebelumnya. Peserta pelatihan juga diberikan ilmu untuk mengetahui tingkat kepuasan nasabah BMT melalui kuesioner. Kuesioner ini dikemas dalam google form untuk memudahkan rekap jawaban responden atau nasabah. Pihak pimpinan BMT, yaitu Ibu Sari sebelumnya menuturkan bahwa salah satu target BMT adalah bisa mengukur tingkat kepuasan nasabah, sehingga hal ini dapat dilaporkan kepada anggota BMT sebagai bahan evaluasi pengembangan BMT selanjutnya.

Tahap ketiga adalah roleplay yang dilakukan setelah mitra mendapatkan pemahaman mengenai operasional perbankan syariah. Proses roleplay dilakukan di laboratorium bank syariah STIE Perbanas Surabaya. Berikut adalah gambaran ruang pelatihan yang dipakai dalam pelatihan operasional perbankan syariah di Lab Bank. 


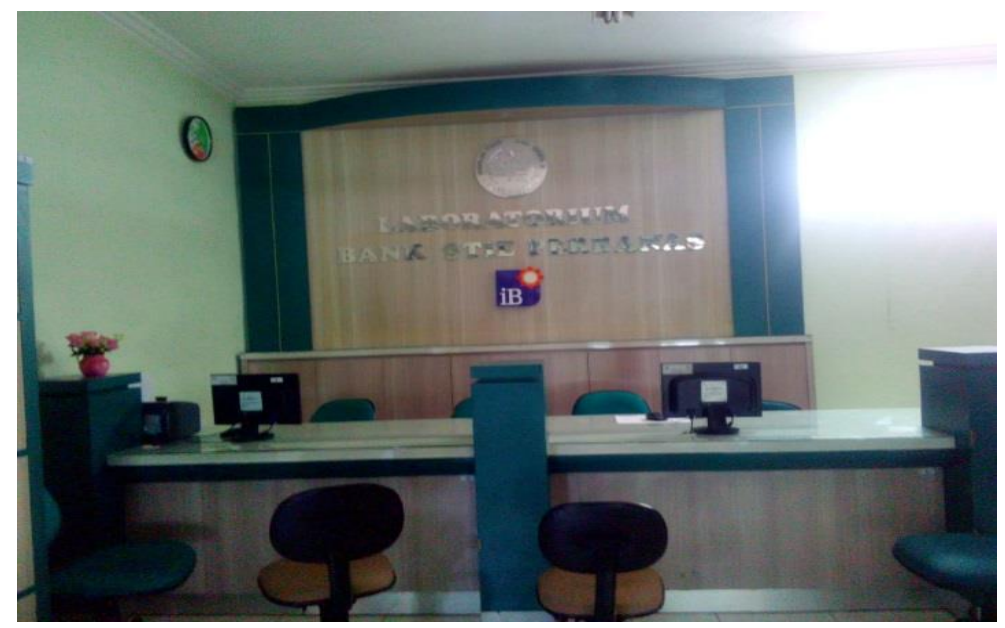

Gambar 3 Ruang Customer Service dan Account Officer di Lab Bank Syariah Perbanas (BSP)

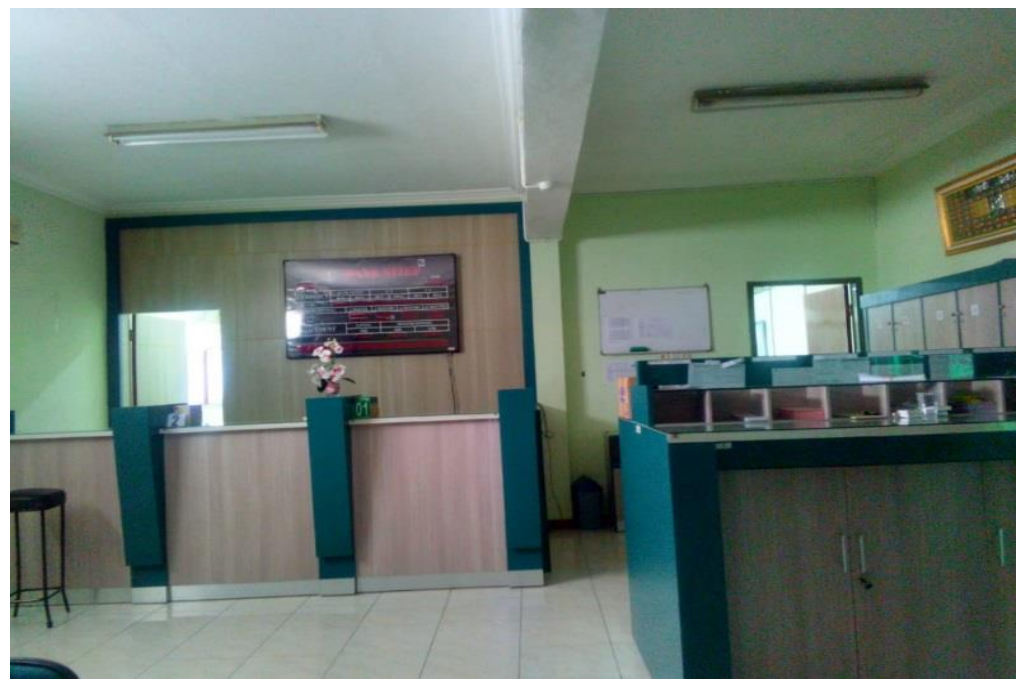

Gambar 4 Ruang Teller di Lab BSP

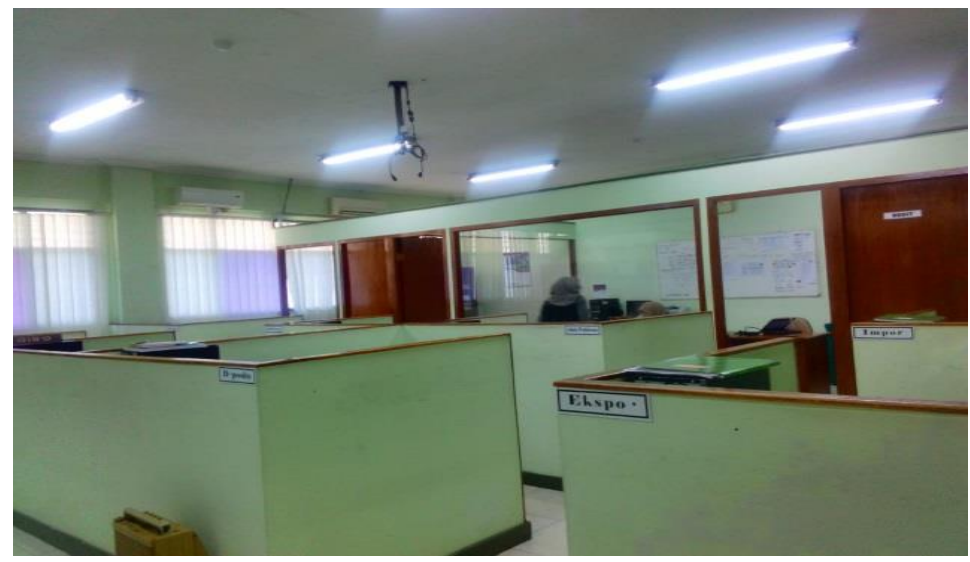

Gambar 5 Ruang Back Office di Lab BSP

Berdasarkan tahapan pelaksanaan di atas kerangka kegiatan pelaksanaan pengabdian maka tahapan pelaksanaan kegiatan di atas maka kepada masyarakat 


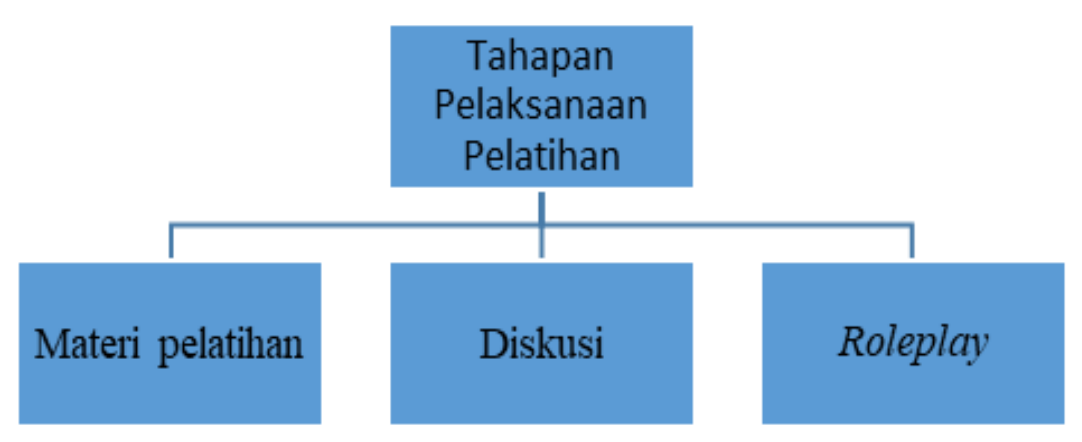

\section{Gambar 6 Tahapan Pelaksanaan}

Keseluruhan kegiatan di atas dapat berjalan lancar dengan adanya dukungan dan partisipasi dari mitra di KSPPS BMT Peniti Kahuripan Muliya. Partisipasi aktif mitra antara lain adalah kesediaan aktif untuk mengikuti materi, diskusi, dan roleplay. Selain mitra, kegiatan ini didukung oleh lab bank STIE Perbanas Surabaya dalam penyediaan sarana dan fasilitas pelatihan.

\section{HASIL DAN PEMBAHASAN}

Dari 12 karyawan BMT, karyawan yang hadir dalam pelatihan sebanyak 5 orang.
Keterbatasan peserta karena pada hari pelaksanaan tersebut kantor BMT masih beroperasi sehingga karyawan yang didelegasikan hanya 5 orang. Walaupun hanya 5 orang, peserta pelatihan ini mewakili masingmasing cabang BMT yaitu cabang Boyolali, Cabang Bandung, dan Cabang Surabaya. Berikut ini adalah nama peserta yang hadir : (1) Atik Fazalena, (2) Elvirda Rizqa Naafi'an, (3) Djoko Herijanto, (4) Khusnul Khotimah, dan (5) Itta Siti Nurochma.

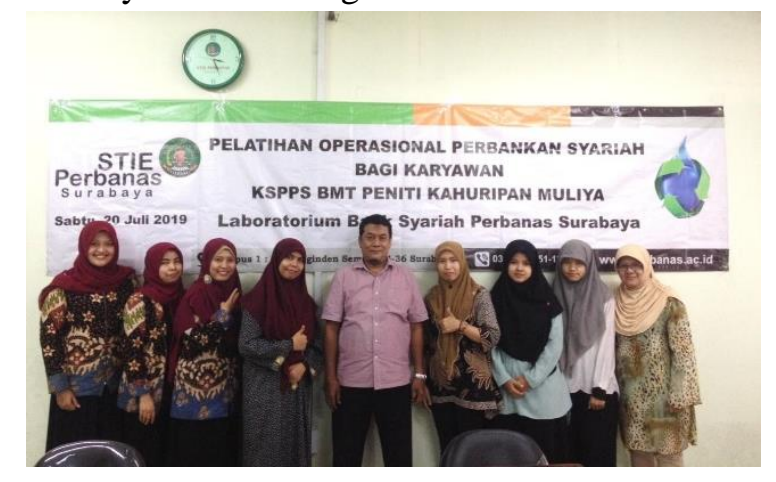

\section{Gambar 7 Peserta dan Narasumber Pelatihan}

Pelaksanaan kegiatan ini dibuka langsung oleh Dr.Dra.Diah

Ekaningtias, Ak.,MM,CA,AAP-B selaku Kabag Pengabdian Masyarakat STIE Perbanas Surabaya. Dalam sambutannya, disampaikan pentingnya pemahaman karyawan akan operasional perbankan syariah supaya dapat menjadi karyawan yang benar-benar menjalankan prinsip syariah dalam pekerjaan. Di samping itu, ditekankan pula pentingnya transaksi yang berdasarkan prinsip syariah dan menghindari adanya riba. Kabag pengabdian masyarakat ini sangat terkesan dengan datangnya peserta dari
Jawa Barat (Bandung) dan Jawa tengah (Klaten) yang datang untuk mengikuti pelatihan ini.

Tahap pertama dalam pelatihan ini adalah penyampaian materi yang disampaikan oleh tim pelaksana dibantu oleh Drs.Ec.Edy Yoelianto,Ak.,M.M. Penyampaian materi bertempat di kampus 1 Gedung B Ruang B204. Pelatihan berlangsung 1 hari pukul 09.00-15.00. Materi dimulai dengan materi pertama yaitu prinsip operasional perbankan syariah yang disampaikan oleh Sholikha Oktavi K., S.E.,M.M. dalam materi ini ditekankan pemahaman peserta akan transaksi yang dilarang dalam perbankan 
syariah dan akad-akad yang ada dalam bank syariah.

Selanjutnya materi kedua dilanjutkan oleh Drs.Ec.Edy Yoelianto,Ak.,M.M. tentang pembiayaan perbankan syariah. Jika dalam materi pertama diperkenalkan pemahaman akan transaksi yang dilarang dalam perbankan syariah berikut juga akad-akad yang mendasari prinsip operasional perbankan syariah, maka dalam materi yang kedua lebih menekankan pembiayaan dengan menggunakan akad murabahah.

Dalam materi pertama dan kedua proses diskusi berlangsung dengan baik. Peserta yang belum paham dapat langsung bertanya kepada narasumber. Pada materi pertama terdapat peserta yang bertanya mengenai definisi dari IMBT. Pada materi kedua, pertanyaan peserta adalah seputar skema dalam proses pembiayaan termasuk alurnya. Antusias peserta terlihat dengan adanya timbal balik dari proses pembelajaran.

Selanjutnya untuk mengatasi kebosanan pada peserta pelatihan, maka penyampaian materi disampaikan dalam bentuk game. Game dalam pelatihan ini menggunakan game kahoot yang berisi tentang pertanyaan-pertanyaan yang diselingi dengan musik dan waktu. Pertanyaan ini memuat sejauhmana pemahaman peserta atas materi yang disampaikan. Game Kahoot disampaikan oleh Zubaidah Nasution, S.E., M.SEI.

Materi yang terakhir berkaitan dengan pembuatan google form sebagai salah satu cara untuk mengetahui kepuasan nasabah. Materi ini disampaikan oleh Elfira Maya Adiba, S.EI., M.SEI. Materi yang dibawakan lebih ditekankan tentang cara untuk mengetahui kepuasan nasabah terhadap pelayanan KSPPS BMT Peniti Kahuripan Muliya. Cara yang diperkenalkan dalam pelatihan tersebut yaitu menggunakan kuesioner yang diadaptasi dari jurnal ilmiah yang telah sebelumnya telah melakukan penelitian untuk mengukur tingkat kepuasan nasabah BMT. Kuesioner tersebut untuk lebih mudahnya dibuat dalam google form.

Mayoritas nasabah KSPPS BMT Kahuripan Muliya adalah pedagang di pasar kembang Surabaya, dimana mereka belum sepenuhnya melek teknologi, sehingga narasumber menyarankan kepada pegawai BMT untuk mewawancarai nasabah sambil mengisi google form. Alasan digunakannya google form adalah untuk kemudahan dalam pengolahan data selanjutnya. Harapannya adalah pihak BMT bisa menggunakan instrumen tersebut untuk mengetahui tingkat kepuasan nasabahnya, sehingga bisa mengambil kebijakan ataupun evaluasi untuk pengembangan BMT yang lebih baik lagi.

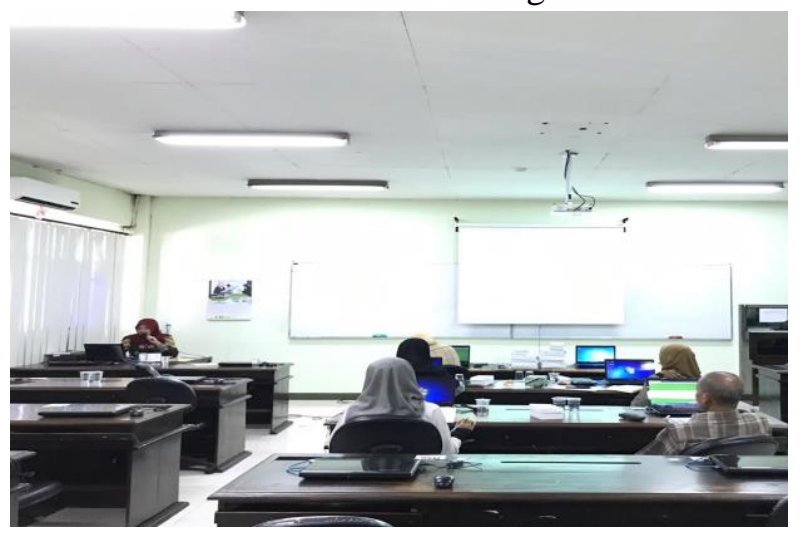

Gambar 8 Kegiatan pelatihan operasional perbankan syariah

Sesi terakhir dalam pelatihan ini yaitu roleplay, dimana peserta berpindah tempat di laboratorium bank syariah STIE Perbanas Surabaya. Roleplay ini dipandu oleh instruktur LOB Syariah yang sudah berpengalaman yaitu Drs.Ec.Edy Yoelianto, Ak., M.M. Roleplay ini dibantu juga oleh mahasiswa untuk mempermudah jalannya acara. Peserta nampak antusias karena dalam roleplay tersebut mereka mengerjakan suatu kasus yaitu kasus dropping pembiayaan. Instruktur juga menjelaskan dengan detail hingga cara pengisian slip dan posting pada 
sistem bank syariah. Roleplay berjalan agak lambat karena ada kendala sistem yang error pada aplikasi LOB. Selain itu, materi ini merupakan hal yang dirasa cukup baru bagi peserta pelatihan sehingga dalam praktik (roleplay) belum bisa cepat. Kendala sistem pada aplikasi LOB ditangani oleh tim IT dan rekan mahasiswa juga membantu peserta dalam roleplay.

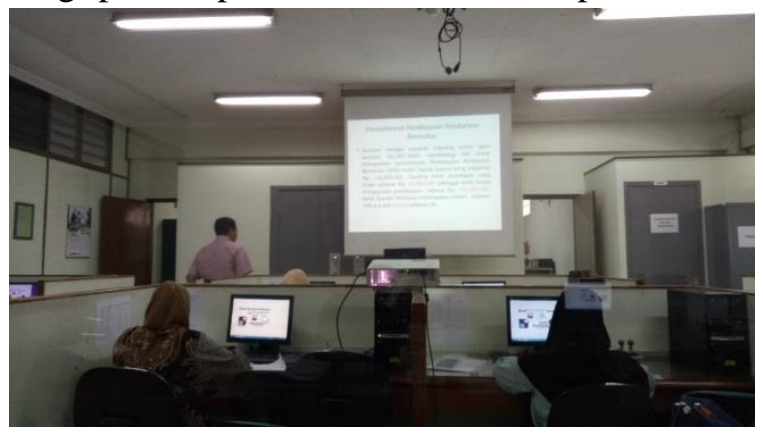

Gambar 9 Roleplay menjadi Pegawai Bank di Lab Bank STIEP

Pelaksanaan pengabdian kepada masyarakat ini diharapkan mampu membantu karyawan BMT ini untuk meningkatkan pengetahuan dan keterampilan terkait operasional BMT yang ada kemiripan dengan operasional Bank Syariah. Untuk mendapatkan hasil yang diharapkan maka memerlukan serangkaian metode pelatihan dimana yang sudah dijelaskan yaitu dari pemberian materi, diskusi, dan diakhiri dengan bermain peran (roleplay) menjadi staf administrasi atau back office. Melalui kegiatankegiatan pendampingan atau pembinaan, BMT melakukan upaya-upaya dalam memaksimalkan peran dalam perbaikan moral masyarakat, upayaupaya tersebut antara lain, pembinaan dari sisi ekonomi atau bisnis dan pembinaan dari sisi nilai-nilai islam atau ruhiyah (Oktavia, 2014)

Aktifitas pelatihan yang telah dilakukan ini, secara normatif seharusnya bisa menambah wawasan dan keterampilan serta cara pandang ataupun perilaku masing-masing individu peserta pelatihan. Pada praktiknya di lapangan, hal ini bisa saja tidak terjadi ataupun berbeda dari pelatihan dikarenakan ada faktor-faktor lain. Hal ini tentu saja berbeda dengan yang diharapkan dengan tujuan diadakannya pelatihan. Adanya kesenjangan pengetahuan dan keterampilan antara instruktur dengan peserta pelatihan menyebabkan adanya perbedaan antara tujuan dengan hasil. Selain itu adanya permasalahanpermasalahan dalam praktik di lapangan bisa saja membuat materi yang sudah disampaikan tidak bisa diterapkan. Oleh karena itu, untuk ke depannya diharapkan adanya pelatihan lanjutan yang lebih intensif atau lebih mendalam pada satu materi tertentu.

\section{SIMPULAN DAN SARAN}

Seluruh kegiatan pengabdian masyarakat ini telah terlaksana yaitu adanya berbagai materi dan pemahaman teoritis mengenai prinsip operasional perbankan syariah, proses diskusi, dan roleplay. Peran serta dan dukungan dari mitra sangat tinggi. Hal ini tercermin dari antusiasnya peserta mengikuti pelatihan dari awal sampai akhir.

Dari 5 peserta pelatihan yang mengikuti pelatihan, 2 peserta datang terlambat dan baru datang pukul 10.00 karena harus menghandle kantor cabang Surabaya. Pada sesi roleplay, 1 peserta ijin meninggalkan pelatihan karena ada kegiatan yang lain. Dari evaluasi yang dilakukan, sebanyak $60 \%$ peserta pelatihan mengikuti jalannya pelatihan dari awal sampai akhir. 20\% peserta yang berhasil memahami materi dan roleplay di lab Bank STIE Perbanas Surabaya.

Berdasarkan kuesioner yang dibagikan, peserta pelatihan sangat terkesan dengan pelatihan ini. Manfaat yang diperoleh setelah mengikuti pelatihan ini adalah peserta pelatihan memperoleh pengetahuan mengenai sistem operasional perbankan syariah, memahami cara kerja BMT yang berbeda dengan bank konvensional, memahami dan menerapkan proses operasional perbankan syariah yang telah sesuai dengan standar.

Hasil kegiatan pelatihan ini adalah peserta pelatihan dapat mengetahui dan memahami alur operasional perbankan syariah yang sesuai 
dengan BMT, mengetahui operasional di perbankan syariah dengan lebih detail dan mendalam. Rekomendasi untuk abdimas selanjutnya adalah mengenai jaminan proses pembiayaan, proses seleksi pembiayaan, mitigasi risiko pada pembiayaan, dan penanganan nasabah/mitra yang bermasalah.
Pada akhir acara dilakukan sesi foto bersama tim pengabdian kepada masyarakat. Berikut adalah tim pengabdian kepada masyarakat beserta dua mahasiswa yang membantu terlaksananya kegiatan ini.

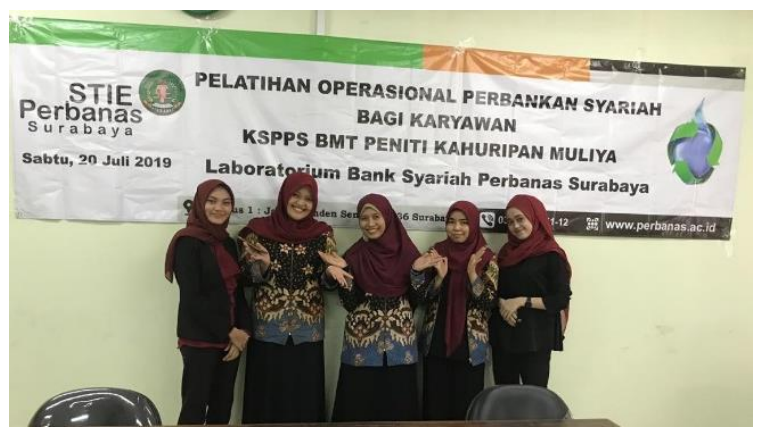

Gambar 10 Tim Abdimas Internal bersama Mahasiswa

\section{DAFTAR PUSTAKA}

Aryani, N., Askandar, N. S., \& Junaidi, J. (2018). Analisis Normatif Undang-Undang No. 1 Tahun 2013 Tentang Lembaga Keuangan Mikro (LKM) Atas Status Badan Hukum Dan Pengawasan Baitul Maal Wat Tamwil (BMT). Jurnal Ilmiah Riset Akuntansi, 7(12).

Dehotman, K. (2016). Pengaruh pendidikan terhadap kinerja karyawan Baitul Mal Wat-Tamwil di provinsi Riau. JEBI (Jurnal Ekonomi dan Bisnis Islam), 1(2), 217-234.

Harahap, S. A. R., \& Ghozali, M. (2020). Peran Baitul Mal Wa Tamwil (Bmt) Dalam Pengembangan Ekonomi Umat. HUMAN FALAH: Jurnal Ekonomi dan Bisnis Islam, 7(1).

Khoirudin, A., \& Akbar, N. (2016). Analisis Permasalahan Koperasi Baitul Maal Wa Tamwil (KBMT) Perkotaan (Studi Kasus KBMT di Kota Bogor). IQTISHODUNA, 12(1), 19-29.

Masyithoh, N. D. (2014). Analisis Normatif Undang-Undang No. 1 Tahun 2013 Tentang Lembaga Keuangan Mikro (LKM) Atas Status Badan Hukum Dan Pengawasan Baitul Maal Wat Tamwil (BMT). Economica: Jurnal Ekonomi Islam, 5(2), 17-36.
Mu'awwanah, U. (2017). Pengaruh Pengetahuan Ekonomi Islam dan Locus of Control Terhadap Kinerja Karyawan BMT UGT SIDOGIRI di Kabupaten Jember. Economic: Journal of Economic and Islamic Law, 7(1), 66-82.

Oktavia, R. (2014). Peranan Baitul Maal Wattamwil (BMT) Terhadap Upaya Perbaikan Moral Masyarakat di Kawasan Dolly Surabaya. IAIN Tulungagung Research Collections, 1(1), 119-137.

Primadhyta, S. (2017). BI Dorong Pengembangan LKM Berbasis Syariah. https://www.cnnindonesia.com/ekonomi/ 20171107181424-78-254140/bi-dorongpengembangan-lkm-berbasissyariah.[diakses tanggal 5 Agustus 2019] Qadariyah, L., \& Permata, A. R. E. (2017). Peran Lembaga Keuangan Mikro Syariah Dalam Perekonomian Di Indonesia: Studi Teoritik Dan Empirik. Dinar: Jurnal Ekonomi dan Keuangan Islam, 4(1).

Sakti, A. (2013). Pemetaan Kondisi Dan Potensi BMT: Kemitraan dalam rangka Memperluas Pasar \& Jangkauan Pelayanan Bank Syariah kepada Usaha Mikro. Al-Muzara'ah, 1(1), 1-18. 